\title{
HUBUNGAN LAMA OPERASI DENGAN TERJADINYA SHIVERING \\ PADA PASIEN OPERASI DENGAN ANESTESI SPINAL DI KAMAR OPERASI RSUD NGANJUK
}

\author{
Dolok Syauqi ${ }^{1}$, Henny Purwandari ${ }^{2}$, Didik Priyono ${ }^{3}$ \\ ${ }^{12}$ STIKes Satria Bhakti Nganjuk, ${ }^{3}$ RSUD Nganjuk \\ Email: syauq_ngk@yahoo.co.id
}

\begin{abstract}
Introduction: The risk of shivering is higher if the duration of surgery is longer, because it will increase the time of exposure to the body with cold temperatures and the accumulation of side effects of spinal anesthesia. The purpose of this study was to determine the relationship of surgical duration and shivering event of surgical patients with spinal anesthesia in surgical suite of Nganjuk General Hospital. Methods: The design of this study was correlation with a cross sectional approach. The research was conducted on August 13-20 2018, at surgical suite of Nganjuk General Hospital. The population was all surgical patients with spinal anesthesia in the Operating Room of Nganjuk General Hospital during on August 13-20 2018, as many as 27 patients. Samples were taken by total sampling technique and obtained a total sample of 27 respondents. The independent variable was surgical duration and the dependent variable was the shivering event. This research instruments were check list sheet and medical record data. Data was analyzed using Coefficient Contingency test with $\alpha=0.05$. Results: The results showed that surgical duration in surgical suite of Nganjuk General Hospital, almost half the duration was in middle level (31-60 minutes) as many as 13 respondents $(48.1 \%)$. Shivering event in the Operating Room of Nganjuk General Hospital, almost half of them were in grade 3 as many as 12 respondents (44.4\%). The results of the Coefficient Contingency test showed pvalue of $0.002 \leq \alpha(0.05)$. So that it can be concluded that Ha was accepted, meaning that there was a relationship between the surgical duration and shivering event of surgical patients with spinal anesthesia in surgical suite of Nganjuk General Hospital. Conslusions: The longer of surgical duration carried out by respondents in the surgical suite of Nganjuk Hospital, the greater the risk of the respondent experiencing shivering events. Conversely, the of shorter surgical duration undertaken by respondents in the surgical suite of Nganjuk General Hospital, the smaller the risk of the respondent experiencing shivering.
\end{abstract}

Keywords: Surgical Duration, Shivering Event, Surgical Patient, Spinal Anesthesia.

\section{PENDAHULUAN}

Teknik anestesi spinal, masih menjadi pilihan yang menguntungkan dalam tindakan operasi, karena selain memiliki kontrol nyeri yang lebih baik, teknik ini juga mampu menghasilkan masa pemulihan post operasi yang lebih cepat, meminimalisir penggunaan jumlah obatobatan anestesi, dan mengurangi penggunaan ruang perawatan intensif (Kresnoadi, 2013). Namun teknik anestesi spinal memiliki efek samping yang umum terjadi pada pasien operasi yaitu terjadinya menggigil (shivering). Risiko terjadinya shivering akan semakin tinggi jika durasi pembedahan semakin lama, karena akan menambah waktu terpaparnya tubuh dengan suhu dingin serta menimbulkan akumulasi 
efek samping anestesi spinal tersebut (Irawan, 2018). Kombinasi dari tindakan anestesi spinal dan lamanya tindakan operasi dapat menyebabkan gangguan fungsi dari pengaturan suhu tubuh yang akan menyebabkan penurunan temperatur inti tubuh, sehingga menyebabkan terjadinya shivering (Fauzi, dkk, 2015). Berdasarkan studi awal yang dilakukan peneliti pada Bulan April 2018 terhadap 10 pasien operasi dengan anestesi spinal, ditemukan sebanyak 5 pasien $(50 \%)$ mengalami terjadinya shivering. Pasien tersebut sebagian besar, yaitu sebanyak 4 pasien termasuk adalah pasien yang menjalani operasi dengan proses lama operasi di atas 1 jam (60 menit).

Angka terjadinya shivering pada anestesi spinal dilaporkan berkisar antara 33\%-57\% (Irawan, 2018). Pada pasien sectio caesarea dengan anestesi spinal, prevalensi terjadinya shivering yang dialami mencapai hingga 85\% (Anggraini, dkk, 2014). Berdasarkan hasil penelitian Budiono (2015) di Rumah Sakit Panti Wilasa Semarang, dari 200 pasien operasi sectio caesarea dengan anestesi spinal ditemukan 92 pasien (46\%) mengalami terjadinya shivering. Sedangkan hasil penelitian Putri (2016) terhadap 29 pasien operasi sectio caesarea yang mengalami shivering, ditemukan pasien yang derajat shivering 0,2 sejumlah 90,6\%; yang mengalami derajat shivering 1 sebanyak $6,25 \%$; dan yang mengalami derajat shivering 4 sebanyak $3,12 \%$. Berdasarkan data rekam medik RSUD Nganjuk selama tahun 2017, jumlah pasien yang menjalani operasi tercatat sebanyak 2.429 pasien. Dari jumlah tersebut, pasien yang diberi anestesi spinal sebanyak 1.158 pasien atau jumlah rata-rata sebanyak 96 pasien. Prevalensi pasien yang mengalami terjadinya shivering selama tahun 2017 sebesar 32\% atau sebanyak 371 pasien.

Efek samping penggunaan teknik anestesi spinal adalah terjadinya gangguan fungsi termoregulator yaitu menurunnya ambang vasokontriksi yang disebabkan karena anestesi spinal menghasilkan blok simpatis, relaksasi otot, dan blok sensoris terhadap reseptor suhu perifer sehingga menghambat respon kompensasi terhadap suhu. Dampak yang muncul dari kondisi tersebut adalah terjadinya reaksi menggigil (shivering) (Masithoh, dkk, 2018). Pada tindakan operasi besar seperti: operasi sectio caesarea, digestive dan trauma, durasi pembedahan yang lebih lama menyebabkan pemanjangan paparan suhu lingkungan dan terbukanya area operasi, sehingga risiko terjadinya efek samping shivering akan semakin besar pula. Walaupun terjadinya shivering merupakan respon normal termoregulasi tubuh, namun perlu diwaspadai dampaknya berupa ketidaknyamanan pasien serta bahaya terjadinya kenaikan kebutuhan oksigen 
akibat peningkatan aktivitas otot (Irawan, 2018). Pada kasus operasi sectio caesarea, lama operasi dapat memicu peningkatan konsumsi oksigen pada ibu inpartu selama terjadinya shivering, sehingga dikhawatirkan dapat menyebabkan hipoksemia yang dapat berdampak buruk bagi kondisi ibu dan janin (Anggraini, dkk, 2014).

Upaya asuhan keperawatan yang efektif untuk mengatasi terjadinya shivering pasca anastesi spinal perlu dipersiapkan dengan cermat sebelum dilaksanakan tindakan operasi besar yang memiliki lama operasi lebih dari 1 jam (60 menit). Cara yang terbaik adalah dengan memperbaiki hemodinamik dan metabolisme tubuh serta menjaga suhu tubuh selama tindakan pembedahan (Anggraini, dkk, 2014). Terjadinya shivering pasca anastesi dapat dicegah dan diatasi dengan berbagai cara, antara lain dengan cara meminimalkan kehilangan panas selama operasi dengan berbagai intervensi mekanik seperti alat pemanas cairan infus, suhu lingkungan yang ditingkatkan, lampu penghangat dan selimut penghangat (Fauzi, dkk, 2015). Selain itu, penggunaan obat-obatan, antara lain: ondansetron, meperidin, klonidin, dan ketamin telah dibuktikan secara klinis dapat menekan aktivitas otot dan meminimalkan terjadinya shivering (Budiono, 2015). Berdasarkan uraian latar belakang di atas, maka peneliti bermaksud mengangkat judul penelitian: Hubungan Lama Operasi dengan Terjadinya Shivering pada Pasien Operasi dengan Anestesi Spinal di Kamar Operasi RSUD Nganjuk.

\section{METODE}

Desain penelitian adalah analitik dengan pendekatan cross sectional. Penelitian dilakukan di Kamar Operasi RSUD Nganjuk tanggal 13-20 Agustus 2018. Populasi penelitian seluruh pasien yang menjalani operasi di Kamar Operasi RSUD Nganjuk selama tanggal 13-20 Agustus 2018, yaitu 27 orang. Teknik sampling menggunakan total sampling dan jumlah sampel 27 responden.

Variabel independen adalah lama operasi dan variabel dependen adalah terjadinya shivering. Instrumen yang digunakan untuk mengukur variabel lama operasi menggunakan data rekam medik selama 2 jam pasca anestesi dengan indikator, meliputi lama operasi: $\leq 30$ menit, 31-60 menit, dan >60 menit. Sedangkan untuk mengukur variabel terjadinya shivering menggunakan check list dengan indikator meliputi tanda-tanda: tidak ada menggigil, derajat 1 (peripheral vasokontriksi), derajat 2 (aktivitas otot hanya pada satu group), derajat 3 (aktivitas otot lebih dari satu group otot), dan derajat 4 (seluruh tubuh menggigil). 
Analisa data menggunakan uji pasien operasi dengan anestesi spinal di Coeficent Contingency $(\alpha=0,05)$ untuk Kamar Operasi RSUD Nganjuk, sedangkan mengetahui hubungan lama operasi dengan terjadinya shivering. Dengan kriteria pengujian: bila $p$-value $\leq \alpha(0,05)$ maka $\mathrm{Ha}$ diterima, sehingga ada hubungan lama operasi dengan terjadinya shivering pada bila $p$-value $>\alpha(0,05)$ maka Ha ditolak, sehingga tidak ada hubungan lama operasi dengan terjadinya shivering pada pasien operasi dengan anestesi spinal di Kamar Operasi RSUD Nganjuk.

\section{HASIL PENELITIAN}

Tabel 1. Hasil Penelitian Lama Operasi dengan Terjadinya Shivering pada Pasien Operasi dengan Anestesi Spinal di Kamar Operasi RSUD Nganjuk, Tanggal 13-20 Agustus 2018

\begin{tabular}{|c|c|c|c|}
\hline Variabel & Kategori & $f$ & $\%$ \\
\hline \multirow{3}{*}{ Lama Operasi } & Singkat & 10 & 37,0 \\
\hline & Sedang & 13 & 48,1 \\
\hline & Panjang & 4 & 14,8 \\
\hline \multicolumn{2}{|l|}{ Jumlah } & 13 & 100 \\
\hline \multirow{5}{*}{ Terjadinya Shivering } & Tidak ada menggigil & 2 & 7,4 \\
\hline & Derajat 1 & 2 & 7,4 \\
\hline & Derajat 2 & 4 & 14,8 \\
\hline & Derajat 3 & 12 & 44,4 \\
\hline & Derajat 4 & 7 & 25,9 \\
\hline Jumlah & & 13 & 100 \\
\hline
\end{tabular}

Hasil penelitian menunjukkan bahwa dari 27 responden, hampir setengahnya yaitu sebanyak 13 responden (48,1\%) lama operasi tingkat sedang. Diketahui pula dari 27 responden, hampir setengahnya yaitu sebanyak 12 responden (44,4\%) mengalami terjadinya shivering derajat 3.

Tabel 2. Tabulasi Lama Operasi dengan Terjadinya Shivering pada Pasien Operasi dengan Anestesi Spinal di Kamar Operasi RSUD Nganjuk, 13-20 Agustus 2018.

\begin{tabular}{|c|c|c|c|c|c|c|c|c|c|c|c|c|}
\hline \multirow{3}{*}{ Lama Operasi } & \multicolumn{10}{|c|}{ Terjadinya Shivering } & \multirow{2}{*}{\multicolumn{2}{|c|}{ Jumlah }} \\
\hline & \multicolumn{2}{|c|}{$\begin{array}{l}\text { Tidak ada } \\
\text { menggigil }\end{array}$} & \multicolumn{2}{|c|}{ Derajat 1} & \multicolumn{2}{|c|}{ Derajat 2} & \multicolumn{2}{|c|}{ Derajat 3} & \multicolumn{2}{|c|}{ Derajat 4} & & \\
\hline & $f$ & $\%$ & $f$ & $\%$ & $f$ & $\%$ & $f$ & $\%$ & $f$ & $\%$ & $f$ & $\%$ \\
\hline Singkat & 2 & 7,4 & 2 & 7,4 & 1 & 3,7 & 4 & 14,8 & 1 & 3,7 & 10 & 37,0 \\
\hline Sedang & 0 & 0,0 & 0 & 0,0 & 3 & 11,1 & 8 & 29,6 & 2 & 7,4 & 13 & 48,1 \\
\hline
\end{tabular}




\begin{tabular}{|c|c|c|c|c|c|c|c|c|c|c|c|c|}
\hline Panjang & 0 & 0,0 & 0 & 0,0 & 0 & 0,0 & 0 & 0,0 & 4 & 14,8 & 4 & 14,8 \\
\hline Total & 2 & 7,4 & 2 & 7,4 & 4 & 14,8 & 12 & 44,4 & 7 & 25,9 & 27 & 100 \\
\hline \multicolumn{3}{|c|}{$p$-value $=0,002$} & \multicolumn{10}{|c|}{$\alpha=0,05$} \\
\hline
\end{tabular}

Tabulasi silang menunjukkan bahwa dari 27 responden, hampir setengahnya yaitu sebanyak 8 responden $(29,6 \%)$ lama operasi tingkat sedang dengan terjadinya shivering derajat 3. Selanjutnya hasil uji Spearman Rank menunjukkan p-value 0,002 $\leq \alpha(0,05)$. Sehingga dapat disimpulkan Ha diterima, artinya ada hubungan lama operasi dengan terjadinya shivering pada pasien operasi dengan anestesi spinal di Kamar Operasi RSUD Nganjuk.

\section{PEMBAHASAN}

\section{Lama Operasi pada pasien Operasi}

\section{dengan Anestesi Spinal di Kamar Operasi RSUD Nganjuk}

Hasil penelitian menunjukkan bahwa dari 27 responden hampir setengahnya yaitu sebanyak 13 responden $(48,1 \%)$ lama operasi tingkat sedang (31-60 menit). Dari 13 responden tersebut, sebagian besar berjenis kelamin perempuan, yaitu sebanyak 9 responden $(69,2 \%)$ dan hampir setengahnya responden memiliki umur 2130 tahun, yaitu sebanyak 5 responden (38,5\%). Hasil uji koefisien kontingensi didapatkan $p$-value jenis kelamin sebesar 0,049 dan $p$-value umur sebesar 0,029. Dengan demikian, jenis kelamin dan umur responden memiliki hubungan yang signifikan dengan lama operasi.

Menurut WHO (dalam Apriansyah, 2015), pasien kamar operasi sebagian besar berjenis kelamin perempuan, karena jenis operasi yang paling umum dilakukan di rumah sakit adalah sectio caesarea (SC) sebagai salah satu cara untuk membantu proses kelahiran janin melalui insisi pada dinding abdomen (laparotomi) dan dinding rahim (histerektomi) dengan lama operasi berkisar 30-40 menit. Hal ini sekaligus terkait dengan faktor umur dimana menurut Apriansyah (2015) umumnya pasien sectio caesarea memiliki umur produktif berkisar 18 sampai 40 tahun.

Berdasarkan uraian di atas, maka peneliti beropini bahwa hampir setengahnya responden di Kamar Operasi RSUD Nganjuk menjalani lama operasi 31-60 menit, karena sebagian besar merupakan pasien perempuan yang menjalani operasi sectio caesarea (SC). Selain itu, diketahui pula sebagian besar umur pasien SC tersebut berkisar 21-30 tahun, yaitu termasuk dalam umur produktif dan umur ideal bagi ibu melahirkan. Lamanya waktu yang dibutuhkan untuk menjalani operasi $S C$ di Ruang Operasi RSUD Nganjuk tidak 
terlalu singkat tetapi juga tidak terlalu lama, yaitu 31-60 menit sesuai dengan waktu normal yang dibutuhkan dalam operasi $S C$ pada umumnya.

\section{Terjadinya Shivering pada Pasien} Operasi dengan Anestesi Spinal di Kamar Operasi RSUD Nganjuk

Hasil penelitian menunjukkan bahwa dari 27 responden hampir setengahnya yaitu sebanyak 12 responden (44,4\%) mengalami terjadinya shivering derajat 3. Dari 12 responden tersebut, setengahnya responden memiliki umur 21-30 tahun, yaitu sebanyak 6 responden (50\%) dan sebagian besar memiliki tingkat pendidikan SMA, yaitu sebanyak 9 responden (75\%). Hasil uji koefisien kontingensi didapatkan p-value umur sebesar 0,000 dan $p$-value pendidikan sebesar 0,031. Dengan demikian, umur dan pendidikan responden memiliki hubungan yang signifikan dengan terjadinya shivering.

Menurut Morgan (dalam Mubarokah, 2017), umur pasien merupakan salah satu faktor utama yang berpengaruh pada terjadinya hipotermi dan mengigil atau shivering. Pasien anak dan lansia memiliki risiko tinggi terjadi komplikasi operasi, termasuk salah satunya adalah terjadinya shivering, sedangkan pada pasien umur dewasa atau umur produktif, risiko terjadinya shivering lebih rendah. Faktor pendidikan mungkin memiliki pengaruh tidak langsung terhadap terjadinya shivering, karena pasien yang berpendidikan tinggi cenderung melakukan persiapan pre operasi yang lebih baik dan patuh pada instruksi tenaga kesehatan. Menurut Notoatmodjo (2011) juga pendidikan memiliki peranan yang besar dalam membentuk pengetahuan seseorang tentang kesehatan. Semakin tinggi tingkat pendidikan seseorang, maka semakin mudah orang tersebut dalam menerima informasi, sehingga semakin banyak pula pengetahuan yang dimiliki.

Berdasarkan uraian di atas, maka peneliti beropini bahwa hampir setengahnya responden mengalami terjadinya shivering derajat 3 atau masih dalam taraf yang normal, dimana hanya beberapa otot klien yang menggigil, tidak sampai seluruh tubuh menggigil (derajat 4). Biasanya dalam derajat ini dianggap belum perlu diberi obat farmakologis, tetapi hanya diberi selimut hangat. Ketahanan tubuh klien operasi dengan anestesi spinal yang mampu bertahan pada shivering derajat 3 dapat disebabkan karena sebagian besar responden tersebut memiliki umur 21-30 tahun, dimana umur tersebut pasien memiliki stamina fisik yang baik dan memiliki ketahanan terhadap penurunan ambang batas suhu sebagai dampak anestesi spinal. Selain itu, pendidikan responden sebagian besar SMA turut memberikan pengaruh secara tidak langsung pada terjadinya shivering, karena responden 
dengan pendidikan SMA memiliki kemampuan berpikir yang lebih logis, sehingga mereka termotivasi untuk melakukan persiapan pre operasi dengan baik serta patuh pada instruksi tenaga kesehatan untuk meminimalkan dampak negatif anestesi spinal yaitu shivering.

\section{Hubungan Lama Operasi dengan}

Terjadinya Shivering pada Pasien

Operasi dengan Anestesi Spinal di

\section{Kamar Operasi RSUD Nganjuk}

Hasil penelitian menunjukkan bahwa dari 27 responden, hampir setengahnya yaitu sebanyak 8 responden $(29,6 \%)$ lama operasi tingkat sedang (31-60 menit) dengan terjadinya shivering derajat 3 . Selanjutnya hasil pengujian Spearman Rank menunjukkan $p$-value $0,002 \leq \alpha(0,05)$. Sehingga dapat disimpulkan $\mathrm{Ha}$ diterima, artinya ada hubungan lama operasi dengan terjadinya shivering pada pasien operasi dengan anestesi spinal di Kamar Operasi RSUD Nganjuk.

Menurut Nazma (2008), secara umum terjadinya shivering dipengaruhi oleh faktor-faktor pencetus antara lain: suhu ruangan, lama operasi, jenis prosedur bedah, status hidrasi, cairan infus dan irigasi serta pemberian anestesi. Menurut Irawan (2008), risiko terjadinya shivering akan semakin tinggi jika durasi waktu operasi atau pembedahan semakin lama, karena akan menambah waktu terpaparnya tubuh dengan suhu dingin serta menimbulkan akumulasi efek samping anestesi spinal tersebut. Hal ini umumnya terjadi pada jenis operasi sedang atau besar yang memakan waktu lebih dari 1 jam (60 menit). Efek samping anestesi spinal pasca anestesi dijelaskan oleh Masithoh, dkk, (2018), yaitu terjadinya gangguan fungsi termoregulator berupa menurunnya ambang vasokontriksi yang disebabkan karena anestesi spinal menghasilkan blok simpatis, relaksasi otot, dan blok sensoris terhadap reseptor suhu perifer sehingga menghambat respon kompensasi terhadap suhu. Dampak yang muncul dari kondisi tersebut adalah terjadinya reaksi menggigil (shivering).

Berdasarkan fakta dan teori di atas, maka dapat disimpulkan bahwa semakin lama durasi operasi yang dijalani oleh responden di Kamar Operasi RSUD Nganjuk, maka semakin besar risiko responden mengalami terjadinya shivering. Sebaliknya semakin singkat durasi operasi yang dijalani oleh responden di Kamar Operasi RSUD Nganjuk, maka semakin kecil risiko responden mengalami terjadinya shivering. Dalam penelitian ini lamanya operasi yang dijalani oleh responden di Kamar Operasi RSUD Nganjuk hampir setengahnya berdurasi selama 31-60 menit memiliki risiko komplikasi sedang (menengah). Karena itu, efek samping anestesi spinal yang dialami oleh responden 
juga berada pada level yang sedang (menengah), yaitu berupa shivering derajat 1 .

Hasil penelitian ini telah berhasil membuktikan adanya hubungan antara lama operasi dengan terjadinya shivering pada pasien operasi dengan anestesi spinal di Kamar Operasi RSUD Nganjuk. Fakta tersebut sekaligus juga mendukung hasil penelitian terdahulu yang dilakukan Masithoh, dkk, (2018), dimana hasil uji tabulasi silang antara lama operasi dengan terjadinya shivering menggunakan uji chi square didapatkan nilai signifikansi $p$-value $\leq \alpha(0,05)$, sehingga dapat disimpulkan bahwa ada hubungan yang signifikan antara lama operasi dengan terjadinya shivering pada pasien pasca anestesi spinal. Hal itu dikarenakan responden terpapar suhu ruangan yang dingin lebih lama, tidak diberikan selimut untuk menutupi tangan, bahu dan leher selama operasi, dan ruangan ber-AC dengan suhu $18^{\circ} \mathrm{C}$, sehingga dapat menyebabkan penurunan temperatur tubuh pasien.

\section{KESIMPULAN}

Berdasarkan hasil penelitian dan pembahasan, maka dapat disimpulkan bahwa lama operasi di Kamar Operasi RSUD Nganjuk, hampir setengahnya menjalani lama operasi tingkat sedang (3160 menit) yaitu sebanyak 13 responden $(48,1 \%)$. Terjadinya shivering di Kamar Operasi RSUD Nganjuk, hampir setengahnya berada pada derajat 3 yaitu sebanyak 12 responden $(44,4 \%)$. Ada hubungan lama operasi dengan terjadinya shivering pada pasien operasi dengan anestesi spinal di Kamar Operasi RSUD Nganjuk. Hal ini sesuai hasil uji Spearman Rank didapatkan $p$-value $0,002 \leq \alpha 0,05$.

Disarankan bagi perawat yang bertugas di Ruang Operasi agar selalu cepat tanggap dalam melakukan asuhan keperawatan pasien pasca anestesi spinal. Asuhan keperawatan yang diberikan adalah dengan memberikan selimut penghangat dan penciptaan suhu ruangan yang hangat di ruang pemulihan untuk mencegah terjadinya shivering pada pasien. Disarankan pula bagi RSUD Nganjuk untuk menyusun SOP pencegahan dan penatalaksanaan asuhan keperawatan terjadinya shivering pada pasien pasca anestesi spinal dan memberikan pelatihan pada perawat di ruang operasi agar dapat melaksanakan SOP tersebut dengan baik.

\section{DAFTAR PUSTAKA}

Apriansyah, Akbar. 2015. Hubungan antara Tingkat Kecemasan Pre-Operasi dengan Derajat Nyeri Pada Pasien Post Sectio Caesarea di Rumah Sakit Muhammadiyah Palembang Tahun 2014. Jurnal Keperawatan Sriwijaya, Volume 2, Nomor 1, Januari 2015

Notoatmodjo, S. 2011. Ilmu Perilaku Kesehatan. Jakarta: Rineka Cipta

Irawan, Dino. 2018. Kejadian Menggigil Pasien Pasca Seksio Sesarea dengan Anestesi Spinal yang Ditambahkan 
Klonidin 30 mcg Intratekal di RSUD Arifin Achmad Pekanbaru, Indonesia. Jurnal Kesehatan Melayu, Vol. 1 No. 2 (April 2018). Hal. 88-92.

Masithoh, Dewi; Ni Ketut Mendri; Abdul Majid. 2018. Lama Operasi Dan Kejadian Shivering Pada Pasien Pasca Spinal Anestesi. Jurnal Keperawatan Terapan, Volume 4, No. 1, Maret 2018. Hal. 14-20.

Mubarokah, Putri. 2017. Faktor-Faktor yang Berhubungan dengan Hipotermi Pasca General Anestesi di InstalasiBedah Sentral RSUD Kota Yogyakarta. Skripsi. Jurusan Keperawatan Politeknik Kesehatan Kementerian Yogyakarta.

Morgan, G. E., \& Mikhail, M. (2013). Clinical Anesthesiology edisi-5. New York: MC.Grow.

Nazma, Diani. 2008. Perbandingan Tramadol 0,5 Mg/Kgbb dan $1 \mathrm{Mg} / \mathrm{Kg} b \mathrm{~b}$ IV dalam Mencegah Menggigil dengan Efek Samping yang Minimal Pada Anestesi Spinal. Fakultas Kedokteran Universitas Sumatera Utara. 